\title{
New Futures for Old Collections - Contemporary Collecting and Community Involvement at the National Museum of Denmark
}

\author{
Mille Gabrie/ ${ }^{1}$
}

\begin{abstract}
In recognition of altered global relations since colonial times, the Ethnographic Collections at the National Museum of Denmark have identified a need to redefine their role in society. The Ethnographic Collections explore new ways of activating old collections - ways, which include contemporary collecting, co-curation and dialogue with the communities from where the collections derive. Through three recent projects, this paper revolves around questions such as: How can we make associations between the old collections and contemporary society? How do we prioritize, when collecting the contemporary? And how do we ensure that community involvement not only challenges the authority of museums, but also informs museological practices in new and constructive ways?
\end{abstract}

Key words: Ethnography, representation, contextualization, partnerships, contemporary collecting, knowledge sharing, co-curation.

\section{Introduction}

When ethnographic museums began appearing around Europe in the nineteenth century, their primary aim was to collect and portray the strange natives of the new worlds. The museum was in essence the physical manifestation of what Mary Louise Pratt has called the 'planetary consciousness'. With this concept, she refers to the ordering of the world, which took place from the Age of Enlightenment and since has formed the basis for a general distinction between Self and Other (Pratt 1992). Together with 'living villages' and 'fairs', the ethnographic museum was one of a few places where western people could get a glimpse of the exotic 'Other' (Coombes 1995). What, from a European perspective, characterized the Other was primitivism - a complete lack of civilization. They were perceived as curios, savages or less than human, as articulated within the discourse of modernity.

However, since the birth of the ethnographic museum, the world has changed considerably. Since WWII, most former colonies have gained independence, and today these newly independent states, as well as the world's indigenous peoples, are reclaiming ownership of their heritage, not only in terms of repatriation, but also with respect to the ways museums manage collections and represent their culture. Secondly, due to globalization, the ethnographic museum is no longer the only place to encounter the world. Museum visitors today are experienced travelers, who either professionally or as tourists have engagements in different parts of the world. But, what is of equal importance is that museum visitors are no longer homogeneously middle- and upper-class people. Today they have an increasingly multicultural composition which more accurately reflects the population. As a consequence, the distinction between Self and Other - once so symptomatic of the ethnographic museum - is being challenged, which stresses a need for the ethnographic museum to reinvent itself.

This article argues that neither colonial collections nor the ethnographic museum itself are redundant. Quite on the contrary, in a time of dramatic changes in technology, climate, political power and access to global resources, their importance is greater than ever. The world's cultures evolve within, and are inevitably affected by the wider world. With collections spanning both time and space, the ethnographic museum holds the potential to contribute to a more nuanced understanding of the cultural diversity of the world. 
In recognition of altered global relations since colonial times, the Ethnographic Collections at the National Museum of Denmark have identified a need to redefine their purpose by exploring new ways of revitalizing its historic collections - ways, which include:

1) Contemporary collecting

2) Reinterpretation and knowledge sharing

\section{3) Co-curation and community involvement}

Through three recent projects: special exhibitions about the Native American Powwow and Navajo weaving traditions respectively and an event on the occasion of the Mexican Día de Muertos, this paper touches upon questions such as: What is the future of the ethnographic museum? Can contemporary collecting help create associations between old collections and present day society? How do we prioritize, when collecting the past? And how do we ensure that co-curation and community involvement not only challenges the authority of museums, but also informs museological practices in new and constructive ways?

\section{Background of the Ethnographic Collections}

Current trends and changes at the Ethnographic Collections can only be fully understood in relation to the origin of the institution and the nature of its collections, as well as key international developments within both ethnography and ethnographic museums.

The National Museum of Denmark is an encyclopaedic museum holding ethnographic, prehistoric and classical collections. These collections have their origin in independent museums that in 1892 were amalgamated under the heading of the National Museum. The ethnographic collections are among the oldest in the world, founded around 1650 and originating in the Royal Danish 'Kunstkammer' of King Frederik III (Gundestrup 1991). When the Kunstkammer was transformed into a public museum in 1807, the ethnographic collections prospered under the direction of Christian Jürgensen Thomsen, who initiated large-scale collecting campaigns in the Danish colonies, which he argued Denmark had an obligation to document. Soon this scope was widened to collecting in other parts of the world through close cooperation with Danes abroad - officials, missionaries and immigrants. In the first half of the nineteenth century, the ethnographic collections increased from 1,450 to 9,000 items and in 1849 it was turned into an independent museum and moved to its present position at the Prince's Palace. Aside from Thomsen's campaigns, collections from around the world came in from other museums, such as the Smithsonian Institution and the Musée d'Ethnographie du Trocadéro, mostly through exchanges of Inuit collections from Greenland.

In the opening exhibition of 1849 , the peoples of the world were organized on account of their technology and presumed level of civilization. Native Americans, for instance, were ranked among 'those nations, which generally do not process metals themselves, and therefore must be regarded as belonging to the lowest stages of civilization' (Thomsen 1852). Just as European travel literature in colonial times informed the 'imperial eyes', museum representations such as this were used to epitomize the culture of what was considered an inferior Other (Pratt 1992).

In 1870, Thomsen's successor Jens Jacob Worsaae - in line with contemporary evolutionary ideas, reorganized the ethnographic exhibitions based on the principle that different peoples of the world represented different stages on an evolutionary continuum. As a consequence, the ethnographic collections were reduced to material comparative to Danish prehistory (Worsaae 1870: v). In Worsaae's displays, peoples of the world were represented through particular selections of their material culture. It was objects such as warrior shirts, clubs and scalps that would come to metonymically characterize Native American culture, thereby stressing 'the boundless brutality and savagery, the inhuman cruelty that dominates the Indians', as explained by one of his main curators, Kristian Bahne Bahnson (Bahnson 1900: 281). On a political level, such representations authorized contemporary colonial expansions, while on a scientific level legitimating the appropriation of Native material culture for the sake of rescuing it for posterity. 
Kaj Birket-Smith, who founded ethnography as an academic discipline in Denmark, reorganized the ethnographic exhibitions in the 1930s. In his exhibition from 1938, evolutionism was abandoned in favor of geographical and diffusionist approaches. Evolving at the museum as the discipline became concerned with collecting artefacts for the sake of understanding the peoples of the world, ethnography became deeply embedded in colonial practices. When the ideology of colonialism was questioned following WWII, many ethnographers consequently began viewing these collections as relics of the discipline's colonial past. Furthermore, when ethnography in Denmark, as in so many other places, abandoned the museum for the university, material culture studies were left behind (Henare 2005). Inspired by structuralist thoughts, emphasis would now be placed on the more intangible aspects of human existence instead, such as language, ideology and religion. One major exception to this general lack of interest in materiality was of course the many investigations of exchange and gift-economies in 'archaic' societies founded on the work of Bronislaw Malinowski and Marcel Mauss.

In the 1980s the ethnographical discipline was characterized by self-criticism and selfreflexivity concerning representations of the Other. While James Clifford and George Marcus discussed polyphony and partial truths in anthropological texts (Clifford and Marcus 1986), Johannes Fabian drew attention to the temporal distancing between the anthropologist and his subject - a distancing, he argued, which denied the latter a co-existence in the present (Fabian 1983). In ethnographic museums, this crisis of representation was triggered in 1969 with William Sturtevant's seminal paper Does anthropology need museums? (Sturtevant 1969), and continued by Karp and Lavine (1986), Michael Ames (1992), Moira Simpson (1996) and Barringer and Flynn (1998).

The need for critical reflection was further enhanced by reactions from the so-called 'source communities'. This term refers to the communities from whom the ethnographic collections originate and refers both to these groups in the past, and to their present day descendants (Peers and Brown 2003: 2). Due to the colonial origin of ethnographic collecting, source communities, especially in settler states such as USA, Canada, New Zealand and Australia, are increasingly questioning the rights of the ethnographic museum. In the struggle for self-determination and cultural rights, organizations such as the American Indians Against Desecration (AIAD), have declared that 'Indian peoples can be your best friends or your worst enemies, but we will no longer be your collections, specimens or objects of antiquity' (Hammil and Cruz 1989: 199). Part of this protest is concerned with control, religious and cultural rights - other parts deal with issues of identity and self-representation.

Museums with ethnographic collections have dealt with the internal and the external critique in different ways. In settler states, source communities are increasingly involved in the management and representation of their own heritage both at the large national institutions, but also through the creation of community museums of their own. In addition, more and more source community individuals are occupying curatorial positions at national museums.

Also, in Europe, there are examples of collaborative work at the ethnographic museums (Lynch 2011, Lynch and Alberti 2010, Nightingale and Swallow 2003, Peers and Brown 2003; 2013, Shelton 2003). A common way to approach the colonial past among European museums is to focus on contemporary global challenges, a tendency also evident in the current naming (and renaming) of museums: Världskulturmuseet in Gothenburg, Wereldmuseum Rotterdam and recently, Weltmuseum Wien. Common to many of these museums is that they - in recognition of the multicultural composition of the society they serve - take on the role of cultural meeting places, as places for public debate with exhibition themes of contemporary relevance such as human trafficking, HIVIAids etc. (Sandahl 2002).

The Ethnographic Collections at the National Museum of Denmark have, since the 1980s, discussed their colonial origins. This has among other things resulted in the return of 35,000 archaeological and ethnographical artefacts to Greenland, a process later addressed as 'Utimut' (Greenlandic for 'return' or 'come home') (Gabriel 2009, Gabriel and Dahl 2007). However, although this return was based on a genuine partnership between the Danish museum and the newly established Nunatta Katersugaasivia (Greenland National Museum), collaborative exhibitions have until recently not been a key priority. When the permanent galleries were reorganized in the early 1990 s, the crisis of representation was dealt with - not by giving source communities a voice in the exhibitions, but by letting the objects speak for themselves. This 
meant very little texts, images and other kinds of interpretations. In these exhibitions, which are still on, the objects are contextualized as art rather than as ethnography. This way, they have been disassociated from the people who were once responsible for their production, but also from the collecting strategies of the past. The result is that they are stuck in an ethnographic present, which is neither historical nor contemporary, but something indefinable in between.

In order to free the Other from the ethnographic time warp and offer him a co-existence in the present, the Ethnographic Collections have identified a need to reorganize their permanent galleries, and in entirely new ways. The three cases below constitute experiments or steps in this direction.

\section{Dynamic cultures - adding time to the Other}

Outside the ethnographic museum, the anthropological discipline has for a long time distanced itself from essentialist notions of culture as an isolated, static entity. Instead, culture is defined as dynamic and the result of human relations. One key objective of the recent initiatives at the Ethnographic Collections is to situate the Other in time. However, how can we emphasize the dynamic nature of societies with nothing but historic collections of the eighteenth and nineteenth centuries? Recognizing that the historic artefacts were collected with an emphasis on the otherness of the Other, are they to be dismissed as colonial residue or do they still have a value?

At the Ethnographic Collections we acknowledge the value of the historic collections, but we recognize a need to supplement them with contemporary collections. After decades of practically no acquisitions apart from what came in through donations, the Ethnographic Collections are taking up contemporary collecting again. But how do we collect the present? Since collecting the whole world is not an option, how do we prioritize? We have most recently focused on cultural phenomena, which stress cultural dynamics and bridges the past and the present. One such phenomenon is Powwow, the Native American dance festival, which today has become a cultural symbol for Native peoples throughout North America. We explored this dance festival in the recent exhibition Powwow - We Dance, We're Alive

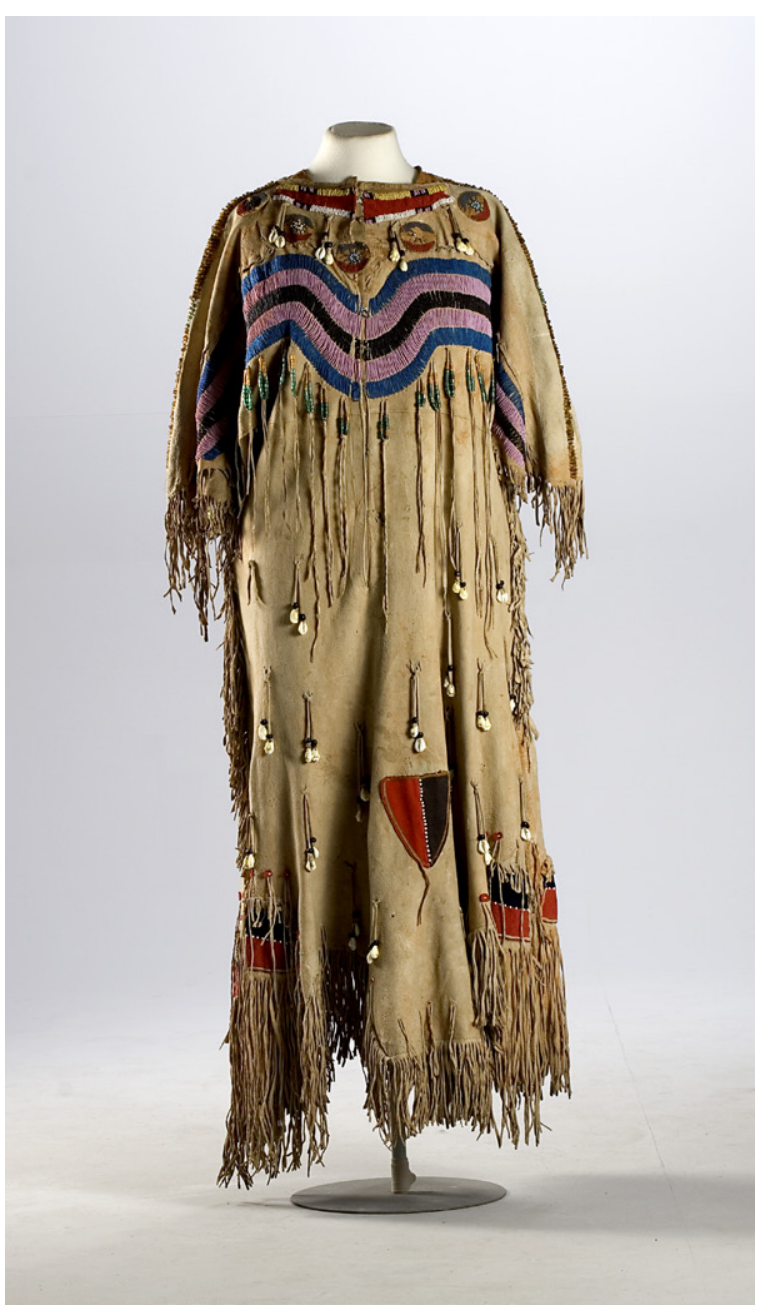

Fig. 1. Dress in deerhide, probably Blackfoot from around 1850. The dress is decorated with rows of beads and cowries on chest and shoulders. Photo: The National Museum of Denmark. 
Powwow is a relatively new tradition, originating only from the 1920 s. However, with the feather-adorned outfits and characteristic dance steps, the Powwow brings ancient symbols back to life. Powwow can be described as an invented tradition (Hobsbawm and Ranger 1983) deriving its authority and authenticity from past cultural and religious expressions, such as nineteenth century warrior shirts, headdresses and adornments. The aim of the exhibition was to stress the dynamic nature of Native American culture and bring to the fore the great significance of traditions, cultural heritage and museum collections in the formation of postcolonial

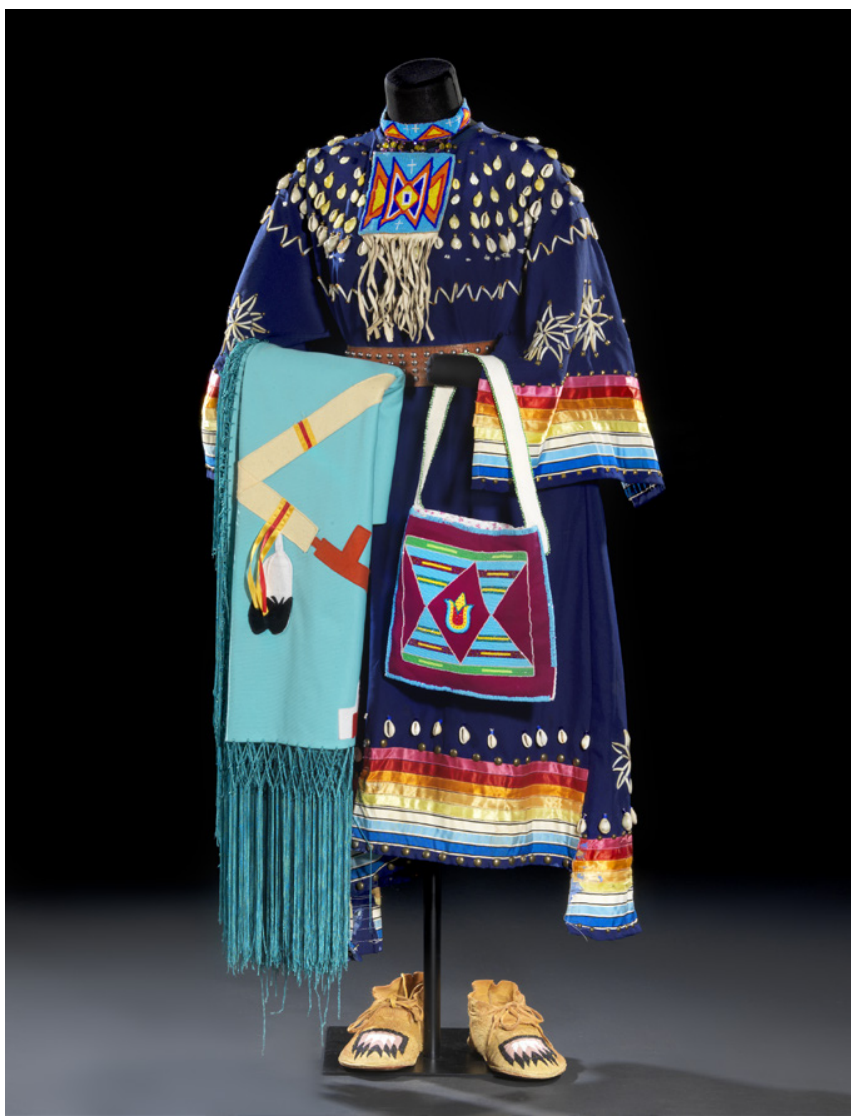

Fig. 2. Outfit for Women's Traditional Dance, collected in the Northern Cheyenne Reservation in 2011. The outfit includes dress, dancing bag, shawl, jewelry and moccasins. Photo: John Lee, the National Museum of Denmark.
Native identities. In order to do this, we wanted to place contemporary every day and Powwow outfits shoulder by shoulder with nineteenth century costumes representing the particular tradition they each reflect and derive from. Even though buckskin today is largely replaced by synthetic fabrics in bright colors, there are striking similarities between the new and old outfits. Female dresses today are decorated with horizontal rows of beads and cowries just as the old ones were (Fig. 1 and 2). Similarly, both the historic and contemporary male outfits contain references to the owner's accomplishments in war-honorary black stripes on the ancient warrior shirts and on the contemporary Men's Traditional Powwow outfits purple hearts and other US military honors (Fig. 3 and 4). However, the National Museum held absolutely no modern collections associated with the Powwow. To make up for this obvious shortage, an affiliated researcher of the Ethnographic Collections with lifelong relations to the Northern Cheyenne Reservation in Montana, went there to purchase modern clothing. What kind of outfits should she aim for? From consultation with Northern Cheyenne individuals and families, it was decided to collect both everyday clothing, such as caps, T-shirts and jewelry, and dance outfits associated with the most common Powwow disciplines: the Women's Traditional Dance, the Grass Dance and the Jingle Dress. Regarding the Powwow outfits, it was decided to aim for used items with personal biographies and purchased directly from families known to the collector and whose members in several instances contributed with video interviews and other types of documentation, which were included in the exhibition. The everyday clothing, on the other hand, was commercially manufactured and bought from stores and craft centers.

Collecting among Native communities is not without ethical dilemmas. As in most other US reservations, the inhabitants of the Northern Cheyenne Reservation are struggling 
with diverse social issues, including poverty enhanced by the recent global economic crisis. The Danish collector experienced more than once that Powwow outfits which she had been offered by Northern Cheyenne families first had to be redeemed from the pawnbroker. That several individuals were embarrassed by this situation became evident from the fact that they subsequently requested to be anonymous both in the exhibition and in the museum inventory database. How do we handle such dilemmas? How do we deal with ongoing political and economic asymmetries, when collecting the present?

\section{The importance of contextualization}

When placing the new and the old side by side, the aim was not only to highlight continuity, but also to discuss how certain materials and designs have been transformed through time. One example is the classic beadwork, which has been recontextualized from personal decoration to collective cultural markers. From once adorning the breast of the warrior testifying to his personal status and place in the world, beadwork is presently being applied to mainstream products such as lanyards and caps and supplemented with slogans such as Native Pride (Fig. 5). Another important example concerns the eagle feathers and the fact that they are increasingly being replaced by artificial ones. This provided the opportunity to discuss contemporary challenges and the clashes between different legal systems, such as nature preservation and Native American religious and cultural rights.

With this focus on the importance of contextualization, we gain inspiration from recent interest in materiality within the anthropological discipline (Gosden and Marshall 1999; Kopytoff 1986; Thomas 1991). When Arjun Appadurai pointed out that objects, like humans, have social lives, it formed the basis of an entirely new approach to material culture (Appadurai 1986). Based on this perspective, an object does not exist outside its context. Each time it changes hands, it becomes re-contextualized, which also applies to the process of collecting (Gosden and Marshall 1999, Thomas 2001). The notion of the 'biography of things', as presented by Igor Kopytoff (1986) and further developed by Chris Gosden and Yvonne Marshall, calls for the museum to bring its own historicity into play as an important part of an object's life trajectory.

The relations and biographies of the major collectors and collections of the nineteenth century have been explored at the Pitt Rivers Museum with the Relational Museum Project, 
(Larson et al. 2007). When planning the Powwow exhibition we sought - on a somewhat smaller scale - to elucidate the rationale of ethnographic collecting, by introducing two of the major Danish nineteenth century collectors in the US, Valdemar Raasløff(1815-1883), Council General in Washington, and Ferdinand Winsløw (1825-1883), banker in Chicago. The anthropologist behind the present day collecting in the Northern Cheyenne Reservation was introduced as well, but in a video interview placed side by side with the Northern Cheyenne individuals she had interviewed, and whose voices added a native perspective to the artefacts on display.

More than simply being a matter of biography, the aim was also to highlight how museum collections are the result of personal choices and curatorial priorities, which are bound to change through time. What was once common practice in museums may no longer be acceptable, for instance the display of human remains. We sought to highlight this by setting up a display case for the scalps and scalp locks that once adorned the personal equipment of the warrior. However, on closer inspection, the display case turned out to be empty apart from a text explaining how the museum has acted out of concern for the Native communities and a QR-code linking to a poll on the museum website addressing the issue of having human remains on display on museums. This caused a vivid debate at the museum, which went all the way to Parliament.

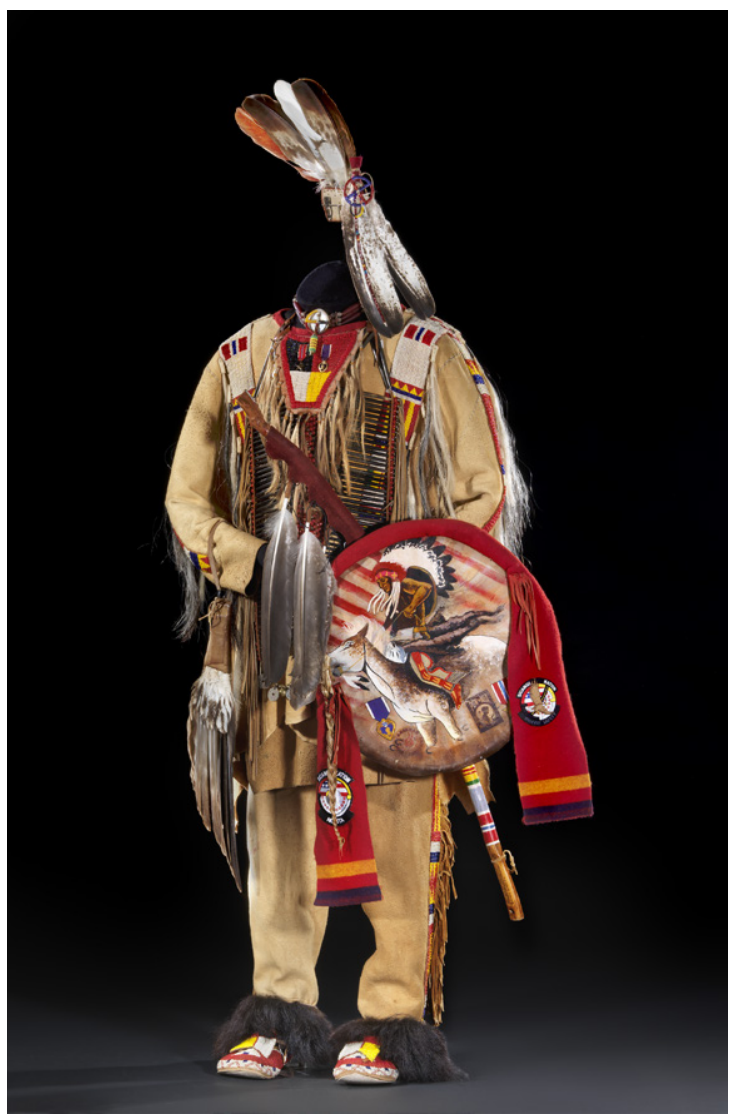

Fig. 4. Outfit for Men's Traditional Dance. The outfit has belonged to Hakikta Najin Jordan, Lakota Sioux and resident in Denmark until his death in 2011. On loan for the exhibition Powwow - We Dance, We're Alive with the courtesy of his widow Marianne TretowLoof Jordan. Photo: John Lee, the National Museum of Denmark.

\section{Co-curation and collecting contemporary arts and crafts}

Although the collection of contemporary Powwow outfits involved consultation, it was never an example of genuine cooperation. With the recent special exhibition Web of the Spider Woman Rugs from Navajo Nation (7 February 2014), the National Museum has explored ways of inviting source community members as co-curators. For this exhibition, the museum's historic collection of Navajo blankets from the late nineteenth century was supplemented by modern Navajo rugs produced by one family of weavers from the Navajo Nation. With this exhibition, it was the aim to share with the public the aesthetics of Navajo weaving traditions, but also to highlight the cultural significance of weaving in contemporary Navajo life. To many Navajo weavers, weaving is not just something you doit is an integral part of life that bridges the past and the present. Weaving is both the personal expression of the weaver and the foundation for and means of transmitting Navajo culture (Bonar 1996: 10).

By inviting ten weavers from three generations to contribute to the exhibition with a rug or a blanket each, we wanted to illustrate the many different ways that tradition is being interpreted in Navajo society. Whereas the grandmother in her eighties applied the diamond twill technique to natural 


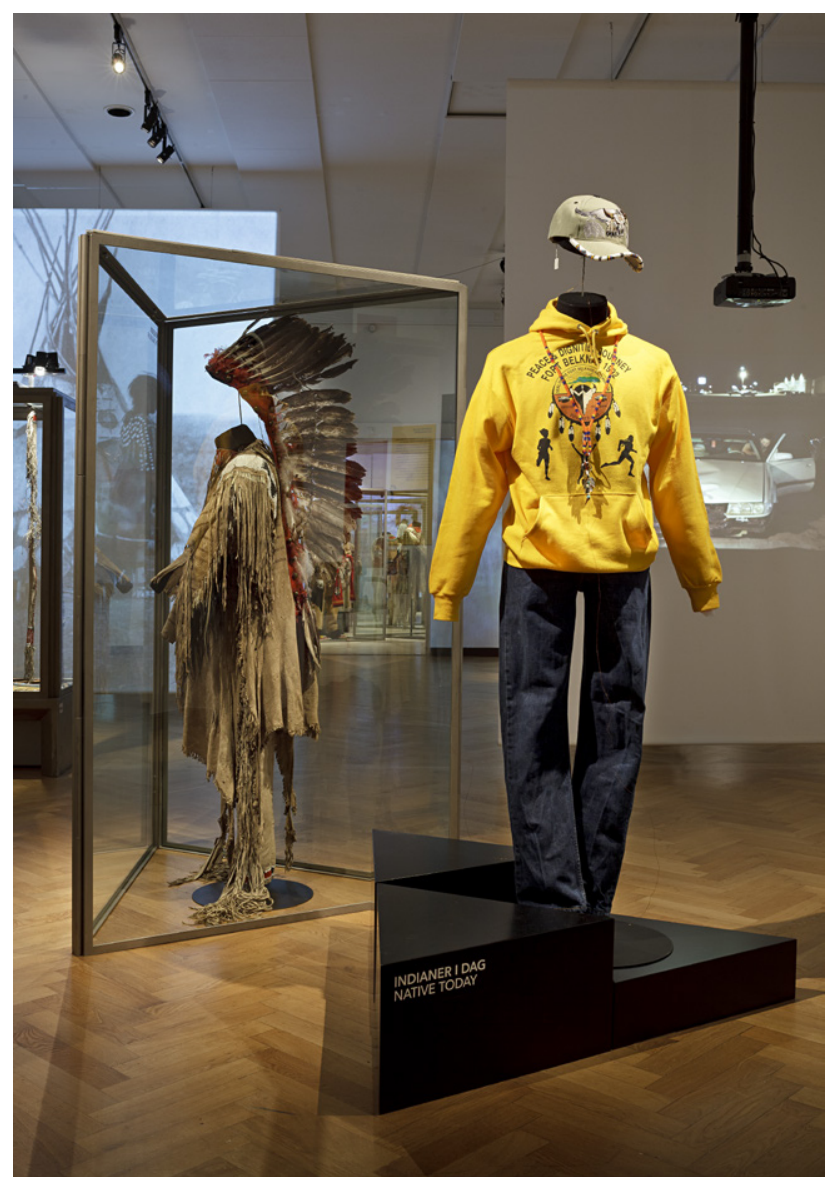

Fig. 5. Hoodie and cap with beadwork from Northern Cheyenne Reservation displayed side by side with 19th century warrior shirt in the exhibition Powwow - We Dance, We're Alive. Photo: Arnold Mikkelsen, the National Museum of Denmark. undyed wool, just as she was taught by her grandmothers, her children and grandchildren experimented with alternative materials, colors and designs, both abstract and pictorial (Fig. 6). Yet, despite the differences, all ten weavings were part of the same tradition, which according to myth, was handed down to the Navajo by one of the most important deities of traditional Navajo religion, Na'ashjéii Asdzáá (the Spider Woman) (Wheat 1984). Aside from the rugs and blankets, the family contributed with photos and video interviews made by and with the youth.

\section{Guest artist}

One of the male weavers of the family, William Whitehair, acted as the museum's contact person and closest partner. As a sort of co-curator, he managed and coordinated the family's contributions, gave advice to the young people, to whom he was also instructor, and organized the transport of the rugs. In addition, he was invited to the National Museum to speak at the opening ceremony, and on his own initiative to demonstrate Navajo weaving traditions as a guest artist at a ten day workshop. The workshop was installed in the exhibition itself surrounded by the historic blankets and the contemporary rugs of his family, including his own giant Chief Blanket, phase 3 (Fig.7). The museum carpenter constructed a loom according to the weaver's directions, and prior to his arrival, he had sent both yarn and weaving tools to the museum to be frozen to eliminate possible pests.

The guest artist attracted large numbers of visitors, especially weaving communities from all over Denmark. They engaged in dialogue with him on technical matters relating to the loom, dye techniques etc. Some of them brought him samples of their own work, and one group performed a traditional Danish weaving hymn for him. The Navajo weaver was welcomed as a fellow weaver and approached as such, rather than as a Native American individual (Fig. 8). Except for one occasion. An academic from the local university one day approached the museum staff and questioned the guest artist's presence in the exhibition, accusing the museum of displaying Native peoples as in the living villages and fairs of the late nineteenth and early twentieth centuries. In this encounter, the guest artist was victimized and deprived of his free will and agency - a very awkward situation for both him and the museum staff. Apparently, the museum had failed to communicate that he was the co-curator of the exhibit, a specialist in Navajo weaving, and present on his own initiative. However, the incident led to some serious considerations: What is the difference between the past human displays and having Native 


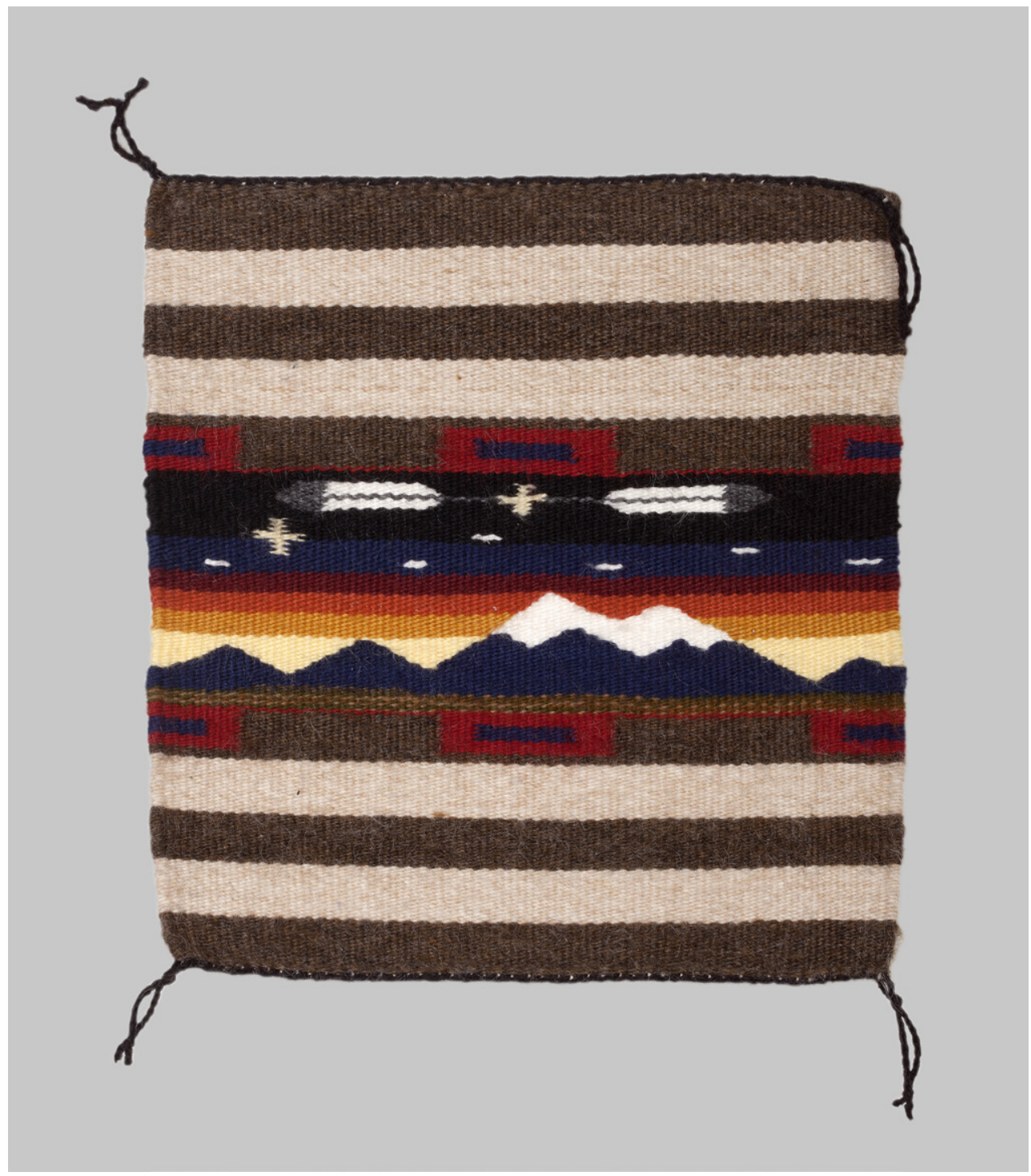

Fig. 6. Rug made by Marklynn Whitehair (age 14) in a combined 'Chief'/'Pictorial' style. The mountain is one of the four sacred mountains, known to the Navajo as Dook'o'oostiíd (in English: the San Francisco Peaks). Photo: John Lee, the National Museum of Denmark.

artists and crafts persons to demonstrate their skills and traditions? How do we address this difference and communicate it to the public?

\section{Contemporary collecting}

As part of the workshop, William Whitehair planned to do a smaller rug during his stay. Prior to his arrival, the museum staff had discussed with him the design of the rug, suggesting a Chief Blanket phase 1, since that particular type was absent in the museum's collections. However, once he came to Copenhagen, as a student in architecture he became so inspired by the cityscape, the canals and the brickwork, that he instead initiated a rug with a geometrical 


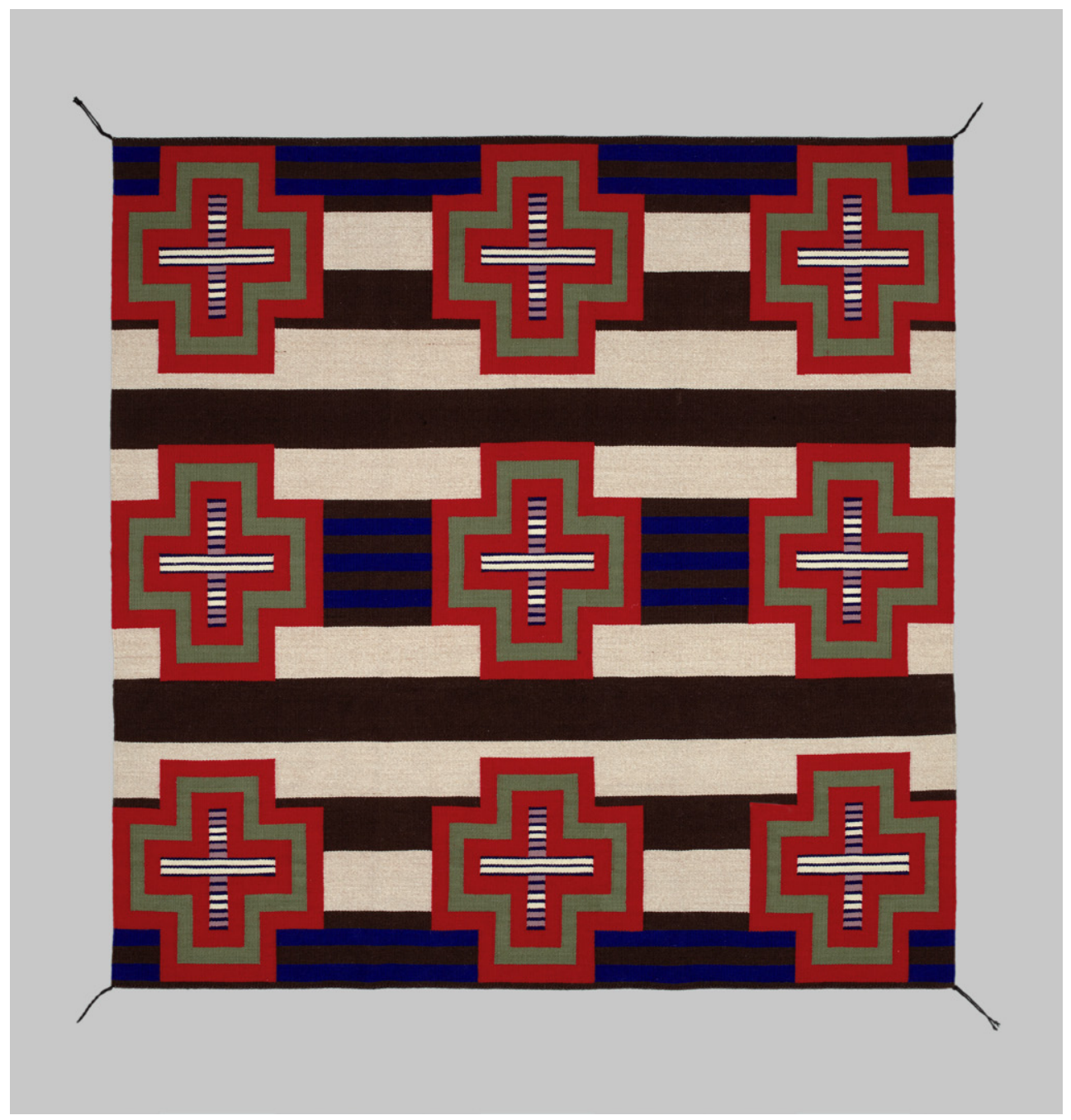

Fig. 7. Chief Blanket, phase 3, made by William Whitehair. Photo: John Lee, the National Museum of Denmark.

design, which included both a bright blue canal and the tower of the Danish Parliament. At first, the museum staff were puzzled with this new rug, which, in time, was to be accessioned by the Ethnographic Collections - was it Navajo or rather Danish? Was it all authentic? Eventually, instead of questioning its authenticity, we came to appreciate its qualities as something intercultural. Michael O'Hanlon has argued that most museum collections constitute 'intercultural documents', telling just as much about the collector as the collected (O'Hanlon 2001). He has argued that 'intercultural nature is not a flaw, an unfortunate shortcoming which must be allowed or compensated for, but the source of their strength' (O'Hanlon 2001: 215). The new Navajo rug in the possession of the National Museum is neither Navajo nor Danish - it is a cultural document that illuminates both Navajo and Danish culture and the relationship between them.

\section{Access, reinterpretation and knowledge sharing}

Implicit in the concept of source communities is the notion that museum collections play an 


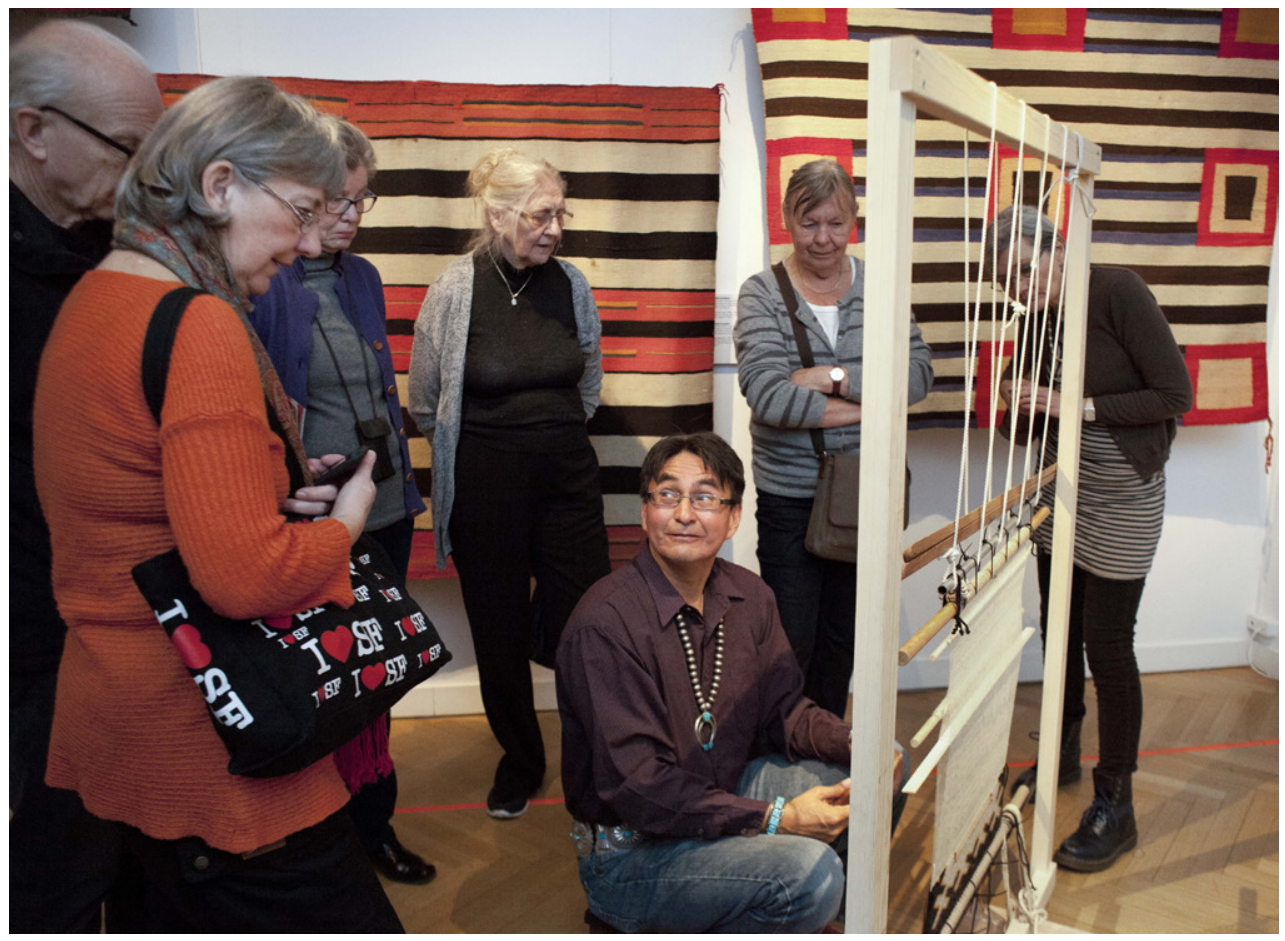

Fig. 8. Navajo weaver William Whitehair in dialogue with Danish weavers. Photo: John Lee, the National Museum of Denmark.

important role to the identities of said source communities, and that museums are to be seen as stewards (Peers and Brown 2003: 2).

In recent years, more and more ethnographic museums work to provide access to museum collections to source communities. As part of the digital revolution, most museums today have ample opportunities to interact with people who are not physically present at the museum (O'Hanlon and Harris 2013). Collections are being digitized and made accessible through museum websites and cross-institutional platforms such as the Reciprocal Research Network and the Inuvialuit Living History, to name but a few such initiatives (Hennessy et al. 2012, Rowley et al. 2010).

The National Museum just recently launched the first stage of the project Collections Online with 50,000 images. However, the majority of the Ethnographic Collections are not yet digitized, just as many source communities do not have regular access to computers or the internet. How, then, can museums accommodate source community legitimate and moral stakes? What museums can do is to provide physical access to collections, either by housing visiting source community members, which is what happened when the Hamburg Museum für Völkerkunde in 1997 housed a group of Yupik elders, or by making collections travel back to their place of origin in order to allow them to reconnect with their source communities (FienupRiordan 2003). The latter took place when warrior shirts from the Pitt Rivers collections visited the Blackfoot community in 2010 (Peers and Brown 2013).

American museums with Navajo blankets, such as the National Museum of the American Indian, have in recent decades invited Navajo weavers to study their collections (Bonar 1996). In the same spirit, the National Museum invited the guest artist to study the historic blankets during his stay. Half of the blankets were on display in the exhibition, but the other half was transported from the storage facilities outside of Copenhagen and arranged on large tables in the museum theater. After going through the collection of 37 rugs and blankets, he declared 
that he found them to be a huge source of inspiration and that it was likely that he would use some of the designs, techniques and patterns in his future weavings.

However, the gain from the study was two-fold: apart from the name of the collector, the museum had only sparse information about its historic Navajo blankets. When going through the collection, the guest artist shared his knowledge with the museum with respect to designs, techniques, colors, fabrics and the extensive symbolism they possess. His interpretations were recorded by the museum and will be added as an important contribution to both the museum database and the coming catalogue. By equating source community knowledge with ethnographic knowledge, we challenge our own authority - we recognize that there are multiple ways of knowing, and that source communities not only have legitimate moral and cultural claims to museum collections, they very often possess a highly specialized expertise.

\section{Co-creation and community involvement}

Models of partnerships have been discussed extensively in recent decades, and there seems to be a 'paradigmatic shift' towards collaborative exhibits (Phillips 2003). The largest transformations are found in places where source communities are local, primarily in settler states. Today, museums in the United States, Canada, New Zealand and Australia are involving their indigenous populations in the representation of their own culture - either through consultation, offering space for self-representation or by facilitating genuine co-productions (Conaty 1989, Peers and Brown 2003, Lonetree and Cobb 2008).

The paradigmatic shift has not yet taken full effect in Europe. Proximity seems to be an important, but not singular reason for this, since face-to-face encounters are important in order to build a relationship (Peers and Brown 2003: 3). How does a European museum overcome the obstacles that huge distances present? One way is to settle on restricted fields when collaborating with distant source communities; for instance, contemporary collecting or re-interpretation of old collections. Another way, which has been explored extensively among European museums in recent years, is to focus on collaboration with source communities living within national borders, primarily diaspora communities, such as migrant workers, refugees etc. (Lynch 2011, Lynch and Alberti 2010, Nightingale and Swallow 2003, Peers and Brown 2003, Shelton 2003). Seeking partners among resident minority groups, provides the museum with the opportunity to become a meeting place, which can actually contribute to the creation of intercultural dialogue on the national level. Based on Mary Louise Pratt's concept of the contact zone, James Clifford has suggested in the often cited Museums as Contact Zones that the museum can serve as a place for cultural contacts, a place that invites to both 'contestation and collaborative activity' (Pratt 1992, Clifford 1997). In a more recent publication, Museum Frictions, Ivan Karp and others have pointed out that owing to globalizing processes, it is important to acknowledge that today 'museological processes [...] can be multi-sited and ramify far beyond museum settings' (Karp et al. 2006: 2).

In general, the attitude of museums experienced in such partnerships is that source communities are to be considered experts on their own lives. Nevertheless, there exist quite contradictory views as to how radically a museum can allow a co-curator to challenge its authority. Is it the museum that is to define the agenda for a given exhibition or event, or is it merely there to facilitate the process? Despite the fact that most formerly colonized peoples have gained independence, it is important to recognize that there are still asymmetrical power relations at play. As Bernadette Lynch and Samuel Alberti have pointed out, it seems to be difficult to escape the colonial mind-set. No matter how good the intentions, we cannot ignore the fact that it is the museum which '... adopts a benevolent position, while the community becomes the beneficiary' (Lynch and Alberti 2010: 14). Although many museums articulate their collaborative efforts as partnerships, they rarely differ from what one could refer to as consultation (Ames 2003). If museums wish to work towards full partnerships, they must be willing to relinquish control over the final product and show what Lynch and Alberti describes as 'radical trust' to their partners (Lynch and Albert 2010: 15). 


\section{Day of the Dead}

At the National Museum of Denmark we have recently initiated a partnership with an organization of citizens of Latin-American origin, primarily Mexican, in connection to the celebration of the Día de Muertos - the Day of the Dead.

In Mexico, the Day of the Dead is one of the most important times of the year. Here, ancient pre-Columbian rituals have merged with the Catholic All Saints' feast into a life-affirming festival for the dead, whose souls are called back to the world of the living to reunite with their loved ones and enjoy all the things they liked best while they were alive. In cemeteries, graves are decorated with flowers and candles, and in order to guide the dead souls back to the world of the living, and the cemetery's paths are covered in orange 'cempasúchil', (marigolds), the favorite flower of the dead. In Mexican homes, altars are created, covered with the deceased family members' favourite treats: cake, fruit, beer, Coca-Cola-maybe even a favorite cigar - but also some of the special things that form part of the festivities: the Bread of the Dead and chocolate and sugar skulls (Carmichael and Sayer 1991, Lomnitz 2005).

By inviting migrants of Mexican descent as partners in the presentation of their own traditions,

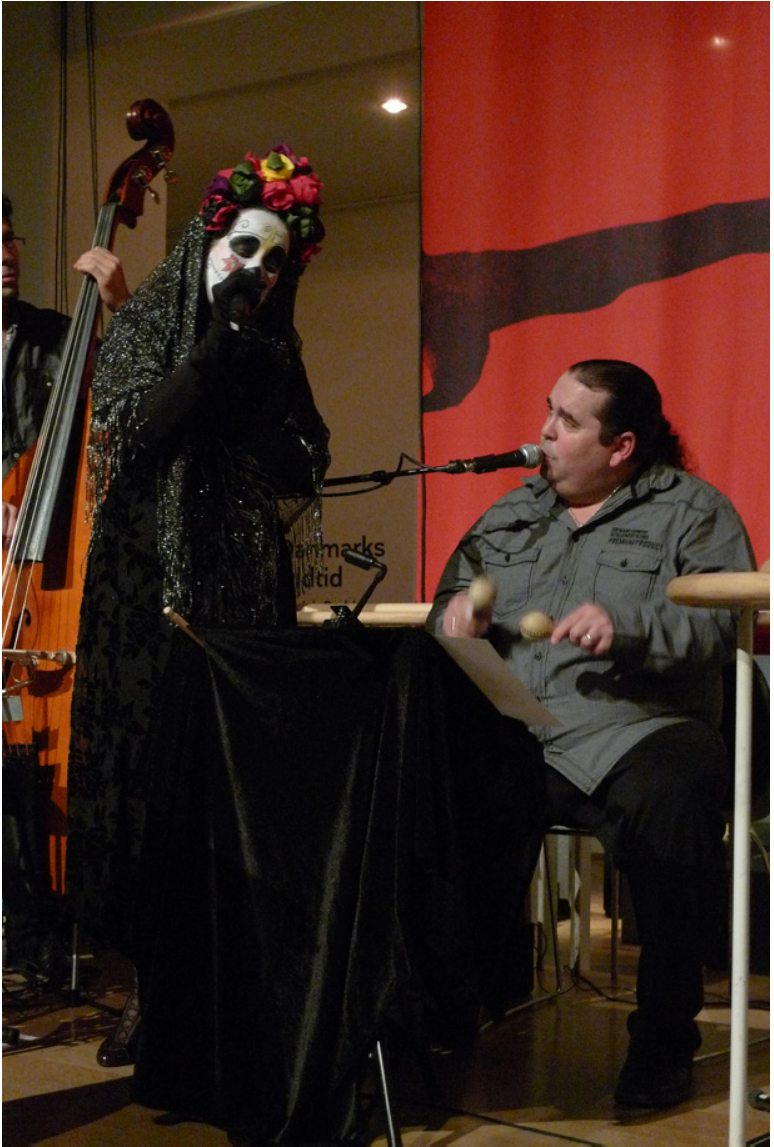

Fig. 9. Mexican singer Edith Tamayo dressed up as La Catarina with Trio Domison at the Day of the Dead. Photo: Mille Gabriel, the National Museum of Denmark. one main goal of the National Museum was to incude them in the national narrative and thereby contribute to creating a sense of belonging. Secondly, the goal was to embrace and strengthen the cultural encounter between Mexican and Danish culture, not least with respect to the very different attitudes towards death. In a protestant society such as the Danish, where many people feel uncomfortable with conversations about death, this event provided a highly appreciated opportunity to reflect on death and celebrate departed ones. On November 2nd, 2013 nearly 2,000 guests, resident Mexicans as well as Danes, families, youths and adults, flocked to the National Museum for the event to enjoy Mexican food, musical performances, films, exhibitions and workshops (Fig. 9). In the main hall, visitors were invited to co-create an installation, writing and posting 'calaveritas' (little skulls) with personal greetings to deceased relatives, and in the workshops, both children and adults alike participated in the decoration of clay skulls, making paper flowers and cutting cardboard skeletons. For the occasion, the Ethnographic Collections prepared a display about the cultural and historical background of the Day of the Dead. Next to this display, the Mexican partners constructed a large altar celebrating side by side a Mexican and a Danish celebrity, Frida Kahlo and the Danish philosopher Søren Kierkegaard, who's bicentennial Denmark celebrated in 2013 (Fig. 10). In five different installations in the permanent galleries of Danish prehistory, the Danish-Mexican 
artist Rama King Nash reflected on the different ways that Danes historically and presently have celebrated their departed ones. Both the collaboration and the event as such was a success. The museum had proven its potential as a cultural meeting place by bridging minority and majority groups, and by initiating an intercultural dialogue. Due to success it was decided to extent the partnership to include a similar event in 2014.

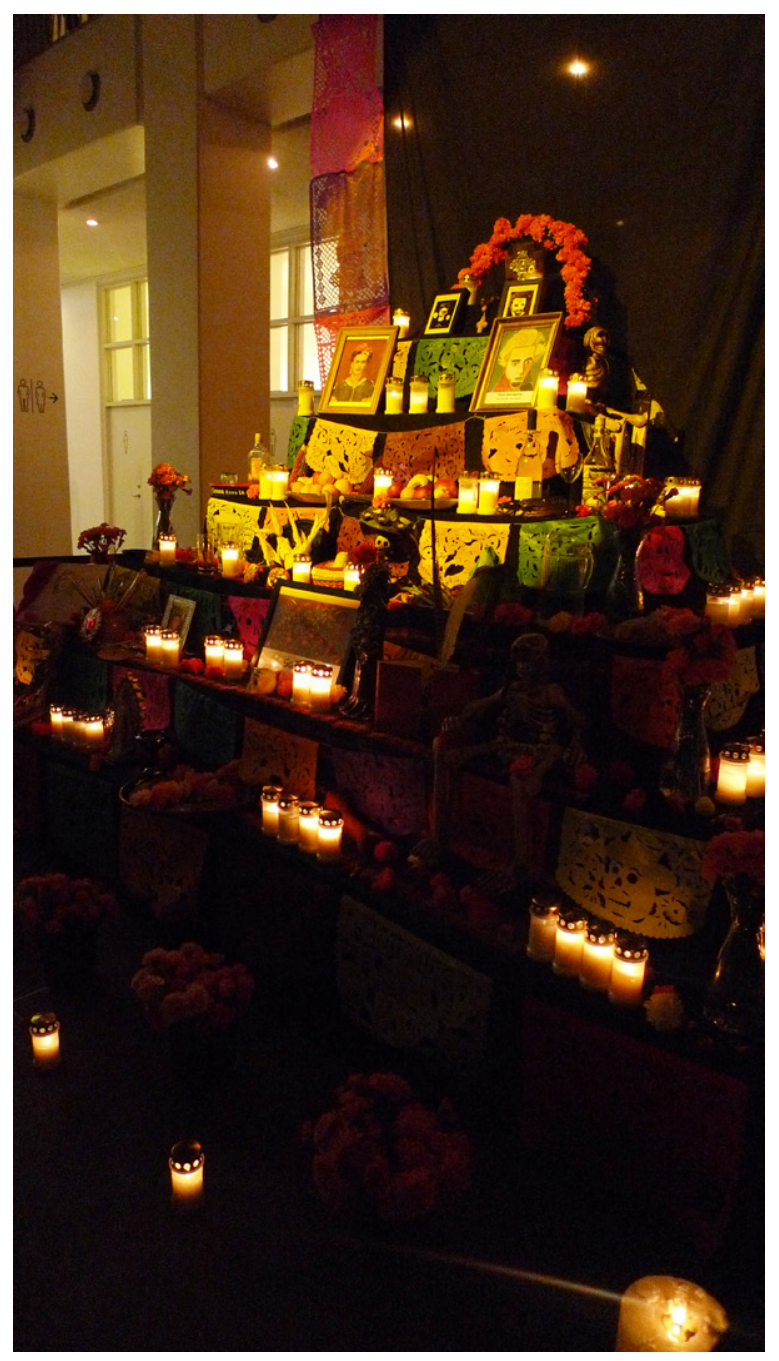

Museums and conflicts

In recent decades museums worldwide have worked within the museum-as-contact-zone perspective. However, even among the larger museums, there seems to be a profound tendency to seek consensus rather than conflict, which at times leads to frustrations on both sides. By refusing to focus on the conflicts that exist in society outside the museum, museums risk becoming irrelevant to the people they invite in as partners. For that reason, Bernadette Lynch has argued that museums should be more than mere contact zones. Based on her own experiences from working with British immigrant populations, she suggests that the museum should take up their place as 'conflict zones' (Lynch 2013).

Nina Simon has argued that in order to succeed in community involvement of any kind, the museum needs to not only have trust in the community's abilities to fulfil the tasks, but they also need to deeply desire their input (Simon 2010: 274). Whathappens when community input pulls in unexpected ways, or, from the museum's perspective, even undesired directions?

Whereas the celebration of the Día de Muertos in 2013 was carried out within an atmosphere of consensus, collaboration in the following year was characterized not only by consensus but also

Fig. 10. Day of the Dead altar celebrating side by side a Mexican and a Danish celebrity, Frida Kahlo and the Danish philosopher Søren Kierkegaard, for whom Denmark in 2013 celebrated the bicentennial of his birth. Photo: Lykke Pedersen, the National Museum of Denmark. by minor conflicts. What was the reason for this? From the museum's perspective, planning the 2013 event was a huge investment in terms of both human and economic resources, and museum staff therefore leaned towards simply repeating the event in 2014. The resident Mexican partners, on the other hand, wanted to develop an entirely new concept. Meeting such very different expectation posed a huge challenge. In the end, a compromise was agreed upon, which included both reuse and new developments - a compromise, which apparently turned out not to be entirely ideal to either party. 


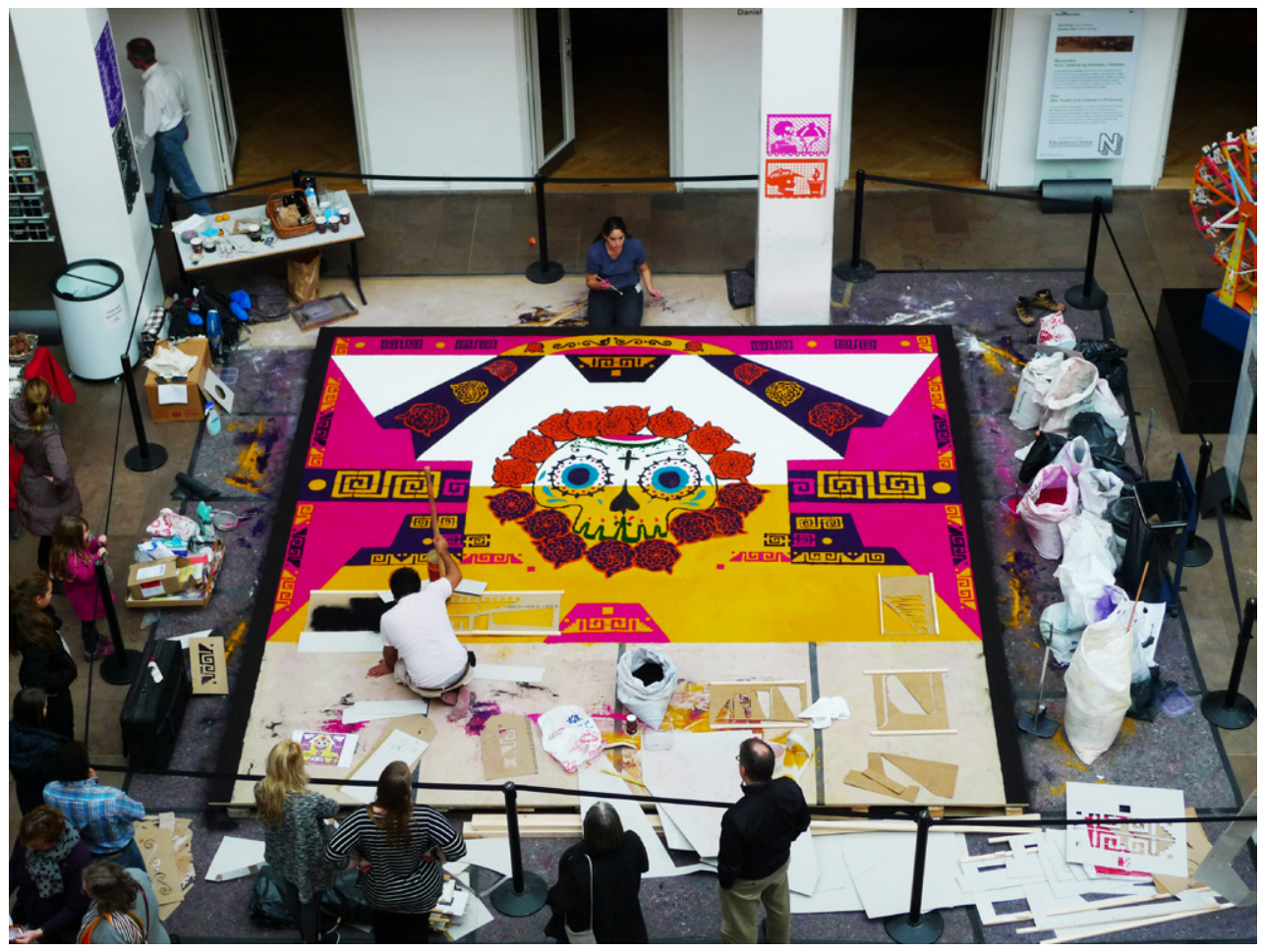

Fig. 11. Mexican artist Pedro César Peralta working on a 'tapete de savarin', a huge image in bright colored sawdust in the grand hall of the museum. Photo: Mille Gabriel, the National Museum of Denmark.

In 2013 the museum experienced that especially the Danish visitors appreciated the traditional or 'authentic' character of the event - the altar, the flowers, the traditional music and crafts. The Mexican partners, on the other hand, wanted to develop something completely different for 2014. As an organization working primarily within contemporary art, they suggested, instead of a traditional altar, to invite the Mexican artist Pedro César Peralta to do a 'tapete de savarin', a huge image in bright colored sawdust - a contemporary art form with roots in tradition (Fig. 11). That could have posed a potential conflict. However, after critical self-reflection, the museum arrived at the conclusion that - just as its recent ethnographic exhibitions stressed the dynamic nature of culture - the right thing to do would be to place radical trust with the partners and allow for a contemporary and more cosmopolitan perspective upon Día de Muertos. Consequently, Pedro César Peraltas was invited, and during the week leading up to the event, his work on the sawdust carpet attracted large numbers of visitors, with whom he engaged in dialogue in the most professional manner. Despite the museum's initial hesitation, it turned out to be an incredibly fruitful cooperation for both parties, not least the museum visitors, who came to experience the museum as a vibrant place.

Another, and more serious object of conflict, had to do with resources. The museum had only limited resources for that year's event. However, every new element inevitably led to more expenses and more work, the extent of which it was difficult to foresee. For instance, the work of the Mexican guest artist required not only funding for his travelling costs and accommodation in Denmark, but also materials to prepare the colored sawdust, paper for protecting the floors, and containers for disposal of the materials afterwards to name a few requirements. In addition, in order for him to finish his work in time, he needed to work till late in the evening for several days leading up to the event. In a large institution such as the National Museum, this required that museum curators also had to stay late or find the resources for hiring regular guards. With limited resources and a full calendar of similar events, this request was difficult to fully 
meet. To external partners, who work on the event on a voluntary basis, such services may be taken for granted. In consequence, any difficulties the museum may have accommodating their requests are likely to be taken as ignorance to their huge contributions. The mere fact that museum staff are being paid, can easily cause a feeling of asymmetry, especially when it comes to migrant communities at times struggling with unemployment.

This takes me to the last object of conflict - the issue of professionalism versus amateurism. Even though a museum perceives source communities as experts on their own lives, there are also other communities to consider, not least the museum visitors, who have certain expectations, when they enter a museum such as the National Museum. They expect to be met by professional museum standards, for instance when it comes to the written material. Based on the museum's general experiences, exhibition texts provided by the Mexican partners were often too long, too complex or abstract, and were in consequence often heavily edited by museum communication staff. On several occasions, the Mexican partners experienced that decisions to cut or alter something were made internally at museum meetings, where they were not present. This naturally caused both anger and a feeling of lack of respect for their contributions.

How could these conflicts have been avoided? And what were the sources of their origin? For one thing, the museum was very eager to reach consensus, and failed to communicate clearly the extent and nature of the invited space. Secondly, in order to pursue consensus, key conflicts existing outside of the museum were ignored, just as the asymmetry inherent in the relations between the museum and the external partners. One cannot ignore the fact that the National Museum represents the state, whereas its partners constitute a minority; in this case not an old diaspora community, but a community made up of individuals who have moved to Denmark primarily because of personal relations. Many of them have experienced the Danish aliens policy as very strict, such as the 24-year-rule, the language tests and the requirements regarding economic support, just as the public debate in Denmark to newcomers may seem both exclusionary and biased. What happens when such a community is given a voice at the museum? On the one hand, being able to present one's own culture at national institutions in the new home country can create both pride and a sense of belonging. On the other hand, any restrictions, rules or objections from the museum may be perceived as a continuation of the process they are going through in becoming Danish citizens. The lesson learned was that, rather than just accommodating cultural contacts based on assumed consensus, conflicts and asymmetries should have been embraced at the museum, just as the museum should have communicated more clearly about its resources and the extent of the invited space. However, all issues were settled before the big event, which once more was welcomed by hundreds of Danish and Mexican participants and once more turned out a huge success.

\section{Conclusion}

This article has argued that even though the world has changed in substantial ways since the birth of the ethnographic museum, this institution certainly has not outlived its usefulness. However, in order to fulfill its potential, the ethnographic museum needs to redefine its priorities so that exhibitions and similar activities reflect the globalized world, of which they form a part, not only in terms of addressing a multicultural audience, but also by acknowledging the colonial origin of its collections and having the courage to question its own natural authority.

Breaking with past modes of representation, which relied on static and essentialist perceptions, I have suggested that ethnographic museums in the future ought to emphasize the dynamic nature of culture, stress the importance of contextualization, and engage in partnerships with the cultures of origin with respect to contemporary collecting, reinterpretation of existing collections and co-curation of exhibitions. Only in this way will the ethnographic museum serve as a meeting place for people and ideas in contemporary society.

Received 11 August 2015

Finally Approved 10 June 2016 


\section{Notes}

1 Special thanks to Viv Golding and Annette Fromm, and the three anonymous reviewers who read and gave comments on this article.

\section{References}

Ames, M. (1992) Cannibal Tours and Glass Boxes: The Anthropology of Museums, Vancouver: UBC Press.

Ames, M. (2003) 'How to decorate a house. The renegotiation of cultural representations at the University of British Columbia Museum of Anthropology', in L. Peers and A. Brown (eds) Museums and Source Communities, 171-180, London and New York: Routledge.

Appadurai, A. (1986) The Social Life of Things. Commodities in Cultural Perspective, Cambridge: Cambridge University Press.

Bahnson, K. (1900) Etnografien. Fremstillet i dens hovedtræk, Copenhagen: Nordiske Forlag.

Barringer, T. and Flynn, T. (eds) (1998) Colonialism and the Object: Empire, Material Culture and the Museum, London and New York: Routledge.

Bonar, E. H. (1996) Woven by the grandmothers. Nineteenth-Century Navajo Textiles from the National Museum of the American Indian, Washington and London: Smithsonian Institution Press.

Carmichael, E. and Sayer, C. (1991) The Skeleton at the Feast - the Day of the Dead in Mexico, London: British Museum Press.

Clifford, J. (1997) 'Museums as Contact Zones', in J. Clifford (ed) Routes: Travel and Translation in the Late Twentieth Century, 188-219, Cambridge, Mass.: Harvard University Press.

Clifford, J. and Marcus, G. E. (eds) (1986) Writing Cultures: the Poetics and Politics of Ethnography, Berkeley: University of California Press.

Conaty, G. (1989) 'Canada's First Nations and Museums', The International Journal of Museum Management and Curatorship 8 (4), 407-413.

Coombes, A. E. (1995) Reinventing Africa: Museums, Material Culture and Popular Imagination in Late Victorian and Edwardian England, New Haven: Yale University Press.

Fabian, J. (1983) Time and the Other. How Anthropology Makes Its Objects, New York: Columbia University Press.

Fienup-Riodan, A. (2003) 'Yupik Elders in Museums. Fieldwork turned on its head', in L. Peers and A. Brown (eds) Museums and Source Communities, 28-41, London and New York: Routledge.

Gabriel, M. (2009) 'Utimut: the Return of Cultural Heritage from Denmark to Greenland', Museum International 241/242, 30-36, Paris: UNESCO.

Gabriel, M. and Dahl, J. (eds) (2008) Utimut: Past Heritage - Future Partnerships. Discussions on Repatriation in the $21^{\text {st }}$ Century, IWGIA Document 122. Copenhagen: IWGIA and NKA. 
Gosden, C. and Marshall, Y. (1999) 'Introduction', in Y. Marshall and C. Gosden (eds) The Cultural Biography of Objects, World Archaeology 31 (2), 169-178, London: Routledge.

Gundestrup, B. (1991). The Royal Danish Kunstkammer 1737, I-II, Copenhagen: Nationalmuseet, Nyt Nordisk Forlag Arnold Busck.

Hammil, J. and Cruz, R. (1989) 'Statement of American Indians Against Desecration Before the World Archaeological Congress', in R. Layton (ed) Conflict in the Archaeology of Living Traditions, 195-199, London: Unwin Hyman.

Henare, A. (2005) Museums, Anthropology and Imperial Exchange, Cambridge: Cambridge University Press.

Hennessy, K., Wallace, R., Jakobsen, N., and Arnold, C. (2012) 'Virtual Repatriation and the Application Programming Interface: From the Smithsonian Institution's MacFarlane Collection to "Inuvialuit Living History"', Museums and the Web 2012, San Diego.

Hobsbawm, E. and Ranger, T. (1983) (eds) The Invention of Tradition, Cambridge: Cambridge University Press.

Karp, I. and Lavine, S. (1986) Exhibiting Cultures. The Poetics and Politics of Museum Display, Washington and London: Smithsonian Institution Press.

Karp, I., Kratz, C., Szwaja, L., and Ybarra-Frausto, T., (2006) (eds) Museum Frictions: Public Cultures/Global Transformations, Durham: Duke University Press.

Kopytoff, I. (1986) 'The Cultural Biography of Things: Commoditization as Process', in A. Appadurai (ed) The Social Life of Things: Commodities in Cultural Perspective, 6491, Cambridge: Cambridge University Press.

Larson, F., Petch, A. and Zeitlyn, D. (2007) 'Social Networks and the Creation of the Pitt Rivers Museum', Journal of Material Culture 12 (3) 211-239.

Lomnitz, C. (2005) Death and the Idea of Mexico, New York: Zone Books.

Lonetree A., and Cobb, A. (2008) The National Museum of the American Indian: Critical Conversations, Lincoln: University of Nebraska Press.

Lynch, B. T. (2011) 'Collaboration, contestation, and creative conflict: On the efficacy of museum/community partnerships', in J. Marstine (ed) The Routledge Companion to Museum Ethics. Redefining Ethics for the Twenty-First-Century Museum, 146-165, London and New York: Routledge.

Lynch, B. T. (2013) Museum as Conflict Zone. Conference Presentation. V\&A Child in the World Conference, 3 Dec. 2013, Museum of Childhood, Bethnal Green, London. http://www.academia.edu/5459089/Museum_as_Conflict_Zone._Dr_Bernadette_ Lynch

Lynch, B. T. and Alberti, S. J. (2010): 'Legacies of prejudice: racism, co-production and radical trust in the museum', Museum Management and Curatorship 25 (1) 13-35.

Nightingale, E. and Swallow, D. (2003) 'The arts of the Sikh Kingdoms - collaborating with a community', in L. Peers and A. Brown (eds) Museums and Source Communities, 55-71, London and New York: Routledge.

O'Hanlon, M. (2001) 'The Field of Collecting. Back to the Future', Folk 43, 211-221. 
O'Hanlon, M. and Harris, C. (2013) 'The future of the ethnographic museum', Anthropology Today 29 (1) 8-12.

Peers, L. and Brown, A. (2003) (eds) Museums and Source Communities. A Routledge Reader, London and New York: Routledge.

Peers, L. and Brown, A. (2013) 'The Blackfoot Shirts Project: Our Ancestors Have Come to Visit', in A. E. Coombes and R. B. Phillips (eds) Museum Transformations, Oxford: Blackwells.

Phillips, R. B. (2003) 'Community collaboration in exhibits', In L. Peers and A. Brown (eds) Museums and source communities, 155-170, London: Routledge.

Pratt, M. L. (1992) Imperial Eyes: Travel Writing and Transculturation, London: Routledge.

Rowley, S., Schaepe, D., Sparrow, L., Sandborn, A., Radermacher, U., Wallace, R., Jakobsen, N., Turner, H., Sadofsky, S. and Goffman, T. (2010) 'Building an On-Line Research Community: The Reciprocal Research Network', Museums and the Web 2010, Denver, Colorado.

Sandahl, J. (2002) 'Fluid Boundaries and False Dichotomies: Scholarship, Partnership and Representation in Museums', INTERCOM Conference Leadership in Museums: Are our Core Values Shifting, Dublin, Ireland.

Shelton, A. (2003) 'Curating African Worlds', in L. Peers and A. Brown (eds) Museums and Source Communities, 181-193, London and New York: Routledge.

Simon, N. (2010) The Participatory Museum, Santa Cruz, California: Museum 2.0.

Simpson, M. G. (1996) Making Representations: Museums in the Post-Colonial Era, London and New York: Routledge.

Sturtevant, W. (1969) 'Does anthropology need museums?', Proceedings of the Biological Society of Washington 82, 619-650.

Thomas, N. (1991) Entangled Objects. Exchange, Material Culture, and Colonialism in the Pacific, Cambridge, Mass. and London, England: Harvard University Press.

Thomsen, C. J. (1852) 'Forerindring', in Kort Veiledning I Det Nye Ethnographiske Museum af C.L. Steinhauer, Copenhagen: Bianco Lunos Bogtrykkeri.

Wheat, J. (1984) The Gift of the Spider Woman: Southwestern Textiles: The Navajo Tradition, Philadelphia: University of Pennsylvania.

Worsaae, J. A (1870) 'Forord', in C. L. Steinhauer (ed) Kort Veiledning i det Kgl. Ethnographiske Museum, Copenhagen: Bianco Lunos Kgl. Hof-Bogtrykkeri. 